\title{
Detergent waste treatment through the modification of biofilter reactors
}

\author{
Suprijandani, Suryono Hadi, Narwati
}

Department of Environmental Health, Poltekkes Kemenkes Surabaya, Indonesia

\begin{tabular}{|c|c|}
\hline Article Info & ABSTRACT \\
\hline Article history: & \multirow{11}{*}{$\begin{array}{l}\text { The use of detergent in households is practiced by almost all people. These } \\
\text { conditions make the quality of the environment, especially water bodies, } \\
\text { more disturbed when the detergent waste disposal without prior processing. } \\
\text { Hazard by detergent can interfere with human health such as digestive } \\
\text { system disorders, skin irritation, and even one of the causes of cancer. The } \\
\text { aimed of this research was to design a modified biofilter reactor to reduce } \\
\text { levels of detergent and other organic substances in domestic wastewater. This } \\
\text { research was a pre-experimental design research with designs used is pre- } \\
\text { test, treatment, and post-test. The research media used were bioball because } \\
\text { bioball has more space on its surface for bacterial growth that will form } \\
\text { bacterial phylum, while activated carbon serves to increase efficiency in } \\
\text { reducing levels of organic matter and to reduce the concentration of } \\
\text { surfactants dissolved. The process is more effective if given a treatment with } \\
\text { a process of coagulation, flocculation, and sedimentation. The results showed } \\
\text { a decrease in detergent content from } 14.56 \mathrm{mg} / \mathrm{L} \text { to } 0.86 \mathrm{mg} / \mathrm{L} \text { ( } 94.1 \%) \text {. } \\
\text { These results indicate that the Bio Filter reactor was effective in reducing } \\
\text { detergent levels to meet the detergent waste standard requirements based on } \\
\text { East Java Governor Regulation No. } 72 / 2013 \text {. }\end{array}$} \\
\hline Received Jan 19, 2021 & \\
\hline Revised May 26, 2021 & \\
\hline Accepted Jun 19, 2021 & \\
\hline Keywords: & \\
\hline Coagulation & \\
\hline Design of bio reactor & \\
\hline Detergent wastewater & \\
\hline Flocculation & \\
\hline Sedimentation & \\
\hline & \\
\hline
\end{tabular}

This is an open access article under the CC BY-SA license.

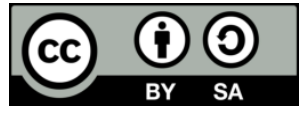

Corresponding Author:

Suryono Hadi

Department of Environmetal Health

Poltekkes Kemenkes Surabaya

Pucang Jajar Tengah 56 Surabaya, Indonesia

Email: hadisur@poltekkesdepkes-sby.ac.id

\section{INTRODUCTION}

The use of detergent in today's daily activities evolved steadily even almost everyone knows and uses detergents to wash their clothes. Detergents may be used in any form (liquid, powder, paste, bar, cake, molded piece, and shape), widely for household laundry products, domestic and industrial cleaners, cosmetic products, and industrial purposes. Laundry detergent is an indispensable commodity used by consumers all over the world [1]. Detergent in various brands of both liquid and powder have circulated to remote countryside with affordable price. The use of detergent that has been widely known in society because this material is very effective and has the ability to clean clothes faster than other materials. Moreover, nowadays, detergent has been added with various deodorizer materials with various kinds of fragrance so it is more liked by the community. But not many people know that detergent has a dangerous risk because its chemical content is very difficult to break down in the environment. Materials that are difficult to decompose in the environment have the potential to disrupt the balance of the ecosystem [2]. Solid and liquid waste dumped into the immediate environment can cause a natural balance of disturbed nature is a soil pollution that is able to change soil $\mathrm{pH}$, the content of mineral change and nutrient disruption of soil for plant life and the polluted 
groundwater resources [3]. The two most important ingredients of detergent forming are surfactants and builders [4]; in Indonesia, generally using Phosphate type Builder. Sodium tri poly phosphate (STPP) is a very important builder after surfactant. STPP has the function of eliminating the minerals in the water, so that the detergent can work optimally [5]. Phosphate in many quantities, may lead to an increase in nutrients (eutrophication) in the body of water. This condition is characterized by explosive growth of algae and water hyacinth that can indirectly harm the biological and environmental biota [6]. Phosphate in many quantities, may lead to an increase in nutrients (eutrophication) in the body of water. This condition is characterized by explosive growth of algae and water hyacinth that can indirectly harm the biological and environmental biota. Detergent has the main forming ingredient, which is a surfactant, which is difficult to decipher by microorganisms. This condition makes the waste of detergent issued daily by the household will become hazardous waste toxic and threatening environmental stability [7]. The more days the existence of detergent in the environment increasingly concerned. The growth of a lot of algae in the water rapidly is one of the negative impacts caused by the waste of detergent. Surfactants are active substances that have different ends of hydrophile (like water) and hydrophobic (fat likes). This material has the function of lowering the water surface tension so that it can release dirt attached to the surface of clothing. The type of surfactant commonly used in detergent is alkyl benzene sulfonate (ABS) which has resistant properties to biological decomposition.

Currently, the surfactant of the ABS type has been replaced by linear alkyl sulfonate (WELD) which can be parsed by biological bacteria (biodegradable). Linear alkyl sulphonate (LAS) has a biodegradation of $90 \%$ while ABS is just $50-60 \%$. ABS turn into straight chain (Linear alkyl sulfonic) that can be in biodegradable, causing detergent can be damaged by microorganisms [8]. The use of detergent in today's daily activities evolved steadily even almost everyone knows and uses detergents to wash their clothes. Detergent in various brands of both liquid and powder have circulated to remote countryside with affordable price. The use of detergent that has been widely known in society because this material is very effective and has the ability to clean clothes faster than other materials. Moreover, nowadays, detergent has been added with various deodorizer materials with various kinds of fragrance so it is more liked by the community. But not many people know that detergent has a dangerous risk because its chemical content is very difficult to break down in the environment. Solid and liquid waste dumped into the immediate environment can cause a natural balance of disturbed nature is a soil pollution that is able to change soil $\mathrm{pH}$, the content of mineral change and nutrient disruption of soil for plant life and the polluted groundwater resources [1]. The two most important ingredients of detergent forming are surfactants and builders [3]. In Indonesia, generally using Phosphate type Builder. Sodium tri poly phosphate (STPP) is a very important builder after surfactant. STPP has the function of eliminating the minerals in the water, so that the detergent can work optimally [4]. Phosphate in many quantities, may lead to an increase in nutrients (eutrophication) in the body of water. This condition is characterized by explosive growth of algae and water hyacinth that can indirectly harm the biological and environmental biota [3]. Another negative impact of surfactants is that it can be the cause of rough skin surfaces, the loss of natural moisture that exists on the skin surface and the increasing permeability of the outer surface. The test results showed that human skin is only able to tolerate the contact of the material with the content of $1 \%$ LAS and alpha olein sulfonate (AOS). The condition causes moderate irritation to the skin in the form of skin that feels rough and scaly. The remaining surfactants in the detergent can form chlorobenzene during the process of chlorination of drinking water treatment by Municipal waterworks [9].

Efforts to minimize pollutants in water bodies can be used adsorbents. Pumice is one of the adsorbents that can reduce pollutants by $74.2 \%$ [10]. However, pumice is difficult to obtain, so another adsorbent material that is easily obtained and has similar characteristics is needed. Research to reduce the level of detergent with a variety of plants is already a lot, such as plant crops (Ipomoea crass caulis) and Velvetleaf (Limnocharis flava). However, there are also methods that use biofilters. Biofilter is a waste water treatment technology that utilizes microorganism growth inherent in the media by forming a layer of biofilms [5]. Biofilters equipped with the addition of activated charcoal has the function of increasing efficiency in lowering the levels of organic materials. In addition, it also lowers the concentration of dissolved surfactants in the laundry waste before being discharged into the aquatic environment. Biofilters with activated carbon can reduce the level of detergent in water. This method was previously only used for drinking water treatment [9]. In the research of Switarto and Sugito [5], the effectiveness of biofilter media, pumice, tile shards, and zeolite combined with activated carbon has the ability to reduce the level of detergent in laundry waste. The efficiency rate with the use of an average aerobic reactor is $96 \%, 92 \%$ and $78 \%$. The discharge flow used is $20 \mathrm{ml} / \mathrm{min}$ with 6 hours of residence time. Water flows continuously. In the research of Suarbawa and Ali [11], bioball has the ability to reduce laundry waste detergent levels processed using an anaerobic fixed bed reactor. Allowance for detergent levels with laundry waste concentration $58.2 \mathrm{mg} / \mathrm{l}$ (Waste 20\%) of $76.13 \%$. bioball used medium diameter of $3.5 \mathrm{~cm}$. Hapsari [12] aimed to compare the effectiveness of bioball 
media with tile fragments in lowering the level of detergent. The results showed that bioball media proved to be more effective in lowering detergent levels compared to tile fractional media. A reduction in the level of detergent of $51 \%$, can be declared still not effective. The weakness of previous research showed that the effectiveness of less optimum (51\%) So that the design of biofilters reactors in the research is equipped with a sedimentation body. The use of this sedimentation body, in previous research has not been used. Based on the research that has been done above, researchers are interested in designing the biofilters build by using bioball modified active charcoal and preceded by pretreatment using flocculation and sedimentation system to reduce the level of domestic waste detergent. The advantage of using a bioball is because it has a large enough room for bacterial growth, while activated charcoal functions to absorb waste residues and eliminate the smell of clean water.

This biofilter modification is one of the wastewater treatments that are important for sustainable development in maintaining ecosystems [13]. The purpose of this research is to make the design of the biofilters reactor modification using the media bioball and activated carbon using pre-treatment system to lower the level of detergent household waste.

\section{RESEARCH METHOD}

This type of research is pre-experiment whose data is obtained by conducting experiments. This type of research is experimental with a one-group pre-post design approach [14]. It aims to know a symptom or influence arising, as a result of certain treatment. This design does not use comparators (controls), but it uses the first observation (pre-test) and then tests the changes that occurred after the experiment. The research site is conducted in workshop/workshop Department of Environmental Health Surabaya. As for the examination of detergent levels conducted in laboratories. The method of reducing detergent levels in this study used two units, namely a settling bath for the coagulation, flocculation and sedimentation processes and a biofilter unit containing bioball media and activated charcoal. This research is the use of alum as a coagulant. Alum in the coagulation process has the ability to bind disolved organiccarbons (DOC) better. In the research of Trinh and Kang, it was shown that the use of alum could reduce DOC $3.1 \%$ compared to using Polialumunium Chloride (PA Cl) [15]. Samples of this research is a solution of saturated detergent made from one brand of detergent in the market which has an average level of $14.75 \mathrm{mg} / \mathrm{l}$. The purpose of making detergent samples so that they can be controlled so that the samples are not affected by the variable. The disruptor variables are for example detergent content that varies from several brands, temperatures, and weather, when samples are taken from household waste. Differences are seen through the testing of differences before and after processing. Detergent levels test using the metylene blue active surfactant (MBAS) method and Spectrophotometry. The processing and presentation of the data are carried out discreditably from the observation results obtained during the experiment Then displayed in the form of laboratory test results table. The effectiveness of the test result is determined by comparison with East Java Governor Regulation Number 72 in 2013 [16], about quality raw waste water for industrial and/or other business activities.

\section{RESULTS AND DISCUSSION}

\subsection{Designing design build reactor biofilter modification}

The results of designing the design of the tool in the study consist of a coagulation tub and a biofilters reactor body consisting of bioball and activated charcoal. The size and construction of a detailed design is shown in the Figure 1.

The biofilter reactor design is as shown in Figure 1, then biofilter reactor is made in the workshop room. The results of the modification of the biofilter reactor are then used as a detergent waste processor according to the research objectives. The modification of the biofilter reactor used in this study can be seen in Figure 2.

The flow discharge setting for six hours of contact time by adjusting the debit is done before conducting the experiment. The next step is the process of bacterial conditioning (seeding) on a biofilters media body with a time of two weeks to obtain growth for the breakdown of detergents. In the process of seeding $\mathrm{pH}$ measured at an average of 7.3 with a daily temperature indicates the range of $300 \mathrm{C}-320^{\circ} \mathrm{C}$. 


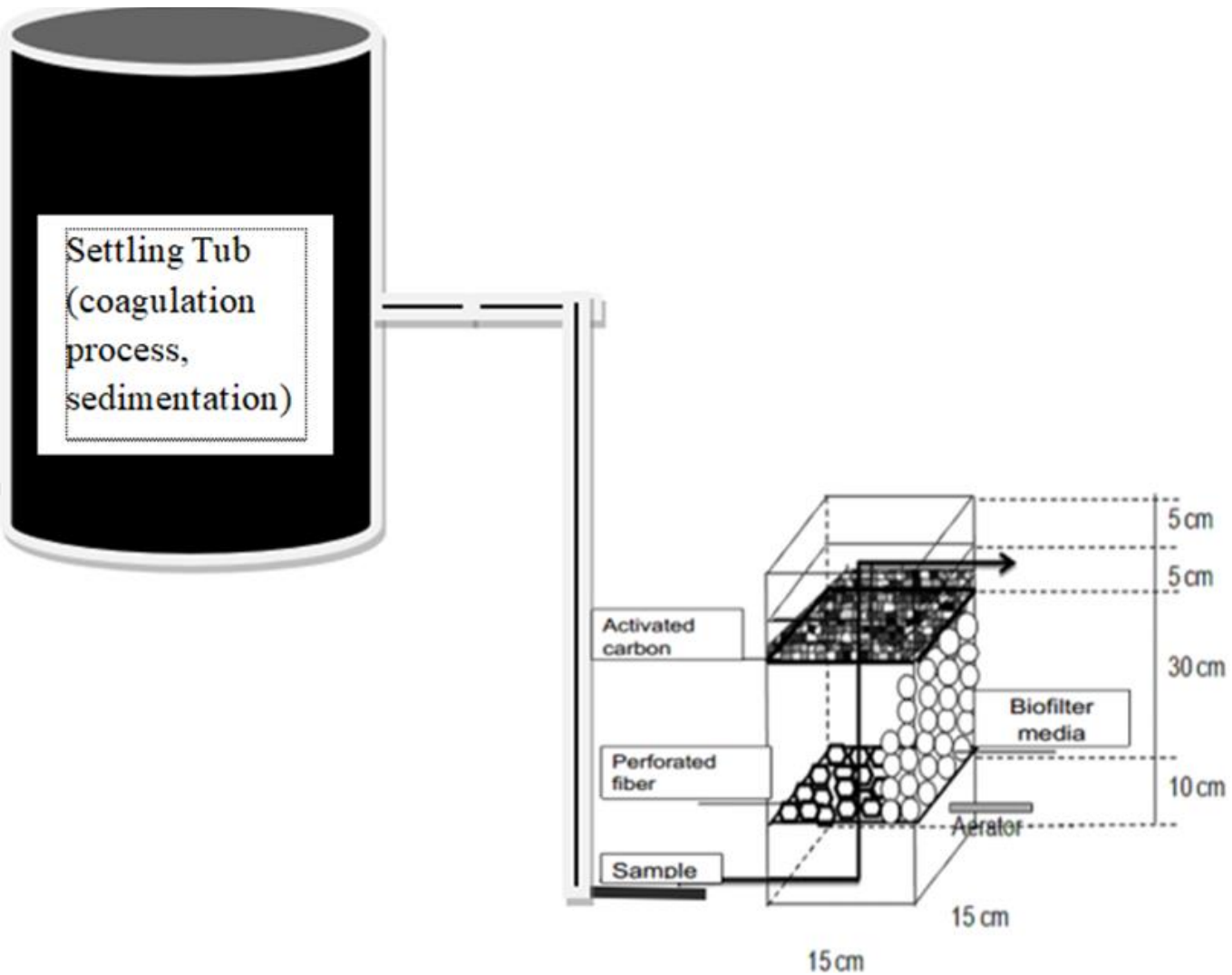

Figure 1. Modification of biofilter reactor design

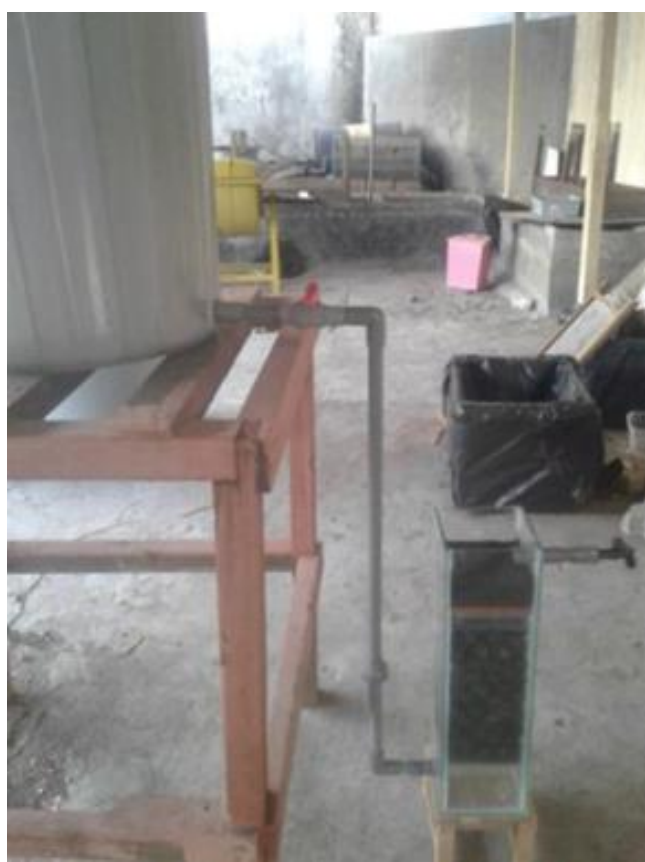

Figure 2. Modification of biofilter reactor

\subsection{Laboratory test results against detergent levels}

The experiment was conducted from August 29 to September 13, 2018, using alum material 0.25 $\mathrm{mg} / \mathrm{l}$ and flow rate of $200 \mathrm{ml} / \mathrm{min}$. In the initial treatment, measurements were taken of 3 samples and the detergent levels were obtained at $14.86 \mathrm{ppm}, 15.02 \mathrm{ppm}$, and $14.19 \mathrm{ppm}$, as shown in Table 1. 
The content of the sample detergent level before the average treatment of $14.69 \mathrm{mg} / \mathrm{L}$. The waste of detergent is processed through the first body of coagulant and flocculation, then taken as many as 16 samples with a time interval of 15 minutes. Laboratory tests show that detergent levels have decreased significantly with successive levels of $3.6 \mathrm{ppm}$ to $0.48 \mathrm{ppm}$ as shown in the Table 2 .

Table 1. Detergent content before treatment

\begin{tabular}{cccc}
\hline No & Code & Levels & Description \\
\hline 1 & C1 & 14.86 & Before treatment \\
2 & C2 & 15.02 & Before treatment \\
3 & C3 & 14.19 & Before treatment \\
\hline
\end{tabular}

Table 2. Detergent levels after through the coagulant tub

\begin{tabular}{cccc}
\hline No & Code & Levels & Description \\
\hline 1 & A1 & 3.6 & Reactor tub 1 \\
2 & A2 & 3.32 & \\
3 & A3 & 2.81 & \\
4 & A4 & 2.62 & \\
5 & A5 & 2.15 & \\
6 & A6 & 1.62 & \\
7 & A7 & 1.12 & \\
8 & A8 & 0.98 & \\
9 & A9 & 0.81 & \\
10 & A10 & 0.74 & \\
11 & A11 & 0.69 & \\
12 & A12 & 0.63 & \\
13 & A13 & 0.58 & \\
14 & A14 & 0.51 & \\
15 & A15 & 0.5 & \\
16 & A16 & 0.48 & \\
\hline
\end{tabular}

The test results showed that there was a reduction in detergent levels from the start of retrieval to final intake. The detergent sample is then processed through the second body of bioball and activated charcoal. After processing in the second tub then taken as many as 16 samples. There was a reduction in detergent levels again, but not as much as in the first processing component indicated by levels of 2.31, 2.01, 1.82, until $0.31 \mathrm{ppm}$, as shown in Table 3.

Table 3. Detergent content after through the biofilter tub

\begin{tabular}{cccc}
\hline No & Code & Levels & Description \\
\hline 1 & B1 & 2.31 & Reactor tub 2 \\
2 & B2 & 2.01 & \\
3 & B3 & 1.82 & \\
4 & B4 & 1.38 & \\
5 & B5 & 1.05 & \\
6 & B6 & 0.71 & \\
7 & B7 & 0.69 & \\
8 & B8 & 0.63 & \\
9 & B9 & 0.51 & \\
10 & B10 & 0.51 & \\
11 & B11 & 0.43 & \\
12 & B12 & 0.41 & \\
13 & B13 & 0.38 & \\
14 & B14 & 0.35 & \\
15 & B15 & 0.33 & \\
16 & B16 & 0.31 & \\
\hline
\end{tabular}

From the Table 3, it can be seen that there is a reduction in detergent levels from the beginning of the intake until the end of treatment. Comparison of test results from before processing using a biofilters reactor body through the two processing tubs can be seen in the Table 4 . 
Table 4. Test result of detergent waste laboratory before and after processing

\begin{tabular}{cccc}
\hline \multirow{2}{*}{ NO } & Detergent waste before process & $\begin{array}{c}\text { Detergent waste after process } \\
\text { Tub 1st }\end{array}$ & Tub 2nd \\
\hline 1 & 14.86 & 3.60 & 2.31 \\
2 & 15.02 & 3.32 & 2.01 \\
3 & 14.19 & 2.81 & 1.82 \\
4 & & 2.62 & 1.38 \\
5 & & 2.15 & 1.05 \\
6 & & 1.62 & 0.71 \\
7 & & 1.12 & 0.69 \\
8 & & 0.98 & 0.63 \\
9 & & 0.81 & 0.51 \\
10 & & 0.74 & 0.51 \\
11 & & 0.69 & 0.43 \\
12 & & 0.63 & 0.41 \\
13 & & 0.58 & 0.38 \\
14 & & 0.51 & 0.35 \\
15 & & 0.50 & 0.33 \\
16 & & 0.48 & 0.31 \\
\hline
\end{tabular}

From the laboratory test results as described in the Table 4, there can be a significant reduction in detergent levels before and after the assessment. There is also a decrease in detergent levels from the results of the first body treatment and the result of processing the second body at each hour of retrieval. The average reduction in detergent levels before processing and after first body treatment amounted to $94.1 \%$.

Table 5 shows that the detergent content of $14.56 \mathrm{mg} / \mathrm{L}$ while the quality of detergent based on East Java Governor Regulation Number 72 in 2013 of $3 \mathrm{mg} / \mathrm{L}$. The experiments on this study used alum coagulants of $0.25 \mathrm{mg} / \mathrm{L}$ with a discharge of $200 \mathrm{ml} / \mathrm{L}$. After screening of two coagulant tub and filtration tubs were obtained a decrease of $94.1 \%$ from an initial rate of $14.56 \mathrm{mg} / \mathrm{L}$ to $0.86 \mathrm{mg} / \mathrm{L}$. When compared with the standard quality standards of waste water detergent level based on East Java Governor Regulation Number 72 in 2013, namely $3 \mathrm{mg} / \mathrm{L}$. The condition indicates that the processing process can already be declared qualified in reducing the level of detergent to be under the standard standards of the specified quality. The results of the percentage reduction in detergent levels of the entire experiment through the Biofilter Reactor tool on this study can be seen in the Table 6.

Table 5. Results of detergent check before processing

\begin{tabular}{cccc}
\hline Parameter & Unit & Test result & Quality standard \\
\hline Detergent & $\mathrm{mg} / \mathrm{L}$ & 14.56 & 3 \\
\hline
\end{tabular}

Table 6. The results of the detergent content test before and after coagulation and filtration processes

\begin{tabular}{ccccc}
\hline $\begin{array}{c}\text { Test result of detergent in } \mathrm{mg} / \mathrm{L} \\
\text { Before }\end{array}$ & After & Difference of decrease & $\begin{array}{c}\text { Percentage of } \\
\text { decrease (\%) }\end{array}$ & Note \\
\hline 14.56 & 0.86 & 13.7 & 94.1 & Maximum limit of detergent level was 3 mg/L \\
\hline
\end{tabular}

\subsection{Tool design}

The measured parameters in this study are anionic detergents, using the Methylene Blue Active Substances (MBAS) method. Performance of bioreactors is seen with the efficiency of decreased detergent content. Design body of detergent processor modified using two bodies. The first body is a driving body. This body is used for coagulation, flocculation and sedimentation processes. Then the second tub is a biofilters body containing media bioball diameter of $3.5 \mathrm{~cm}$ and layer of activated charcoal.

This research is the result of modification of domestic waste treatment construction in previous research by adding a coagulation body before being passed biofilters containing bioball and activated charcoal media. The addition of a control body with coagulation, flocculation, and sedimentation with biofilters body with bioball and activated charcoal has been proven very effective to reduce the level of detergent in sample water. The end result of processing with the modified construction can decrease up to $94.1 \%$.

The coagulation process can bind to the level of detergent along with other organic substances that are negatively charged, then slowly forming a flok of larger size. With the larger type of weight, the floc will settle so that the level of detergent will decrease together with other organic substances. Applicability of coagulation-flocculation for wastewater for textile, tannery, removal of surfactants for Detergent Wastewaters, as primary treatment before membrane application for dairy wastewater, heavy metal removal 
for leachate wastewater and also for Sand ballast flocculation for water treatment which indicates efficiency and applicability of this technology [17].

The decline that occurs in the tub is continued with the process of reducing detergent in the biofilter tub. Before the process of processing is done seeding process that aims to conditioned bacteria on the Bioball media thrives so that the decline in biofilters will be better.

\subsection{Seeding process}

The seeding stage is performed to grow the microorganism used for research. The correct seeding process will greatly support the success of this experiment. Bioball media that has a very wide surface that is $200-240 \mathrm{~m} 2 / \mathrm{m} 3$ provides the potential where the growth of bacterial parser more detergent. The seeding process requires the optimum temperature for bacteria growth of about $25^{\circ} \mathrm{C}-37^{\circ} \mathrm{C}$. While the pH Optimum for bacterial growth around 6.5-7.5 [18], another factor that affects the treatment of seeding is the place where the seeding is done should be protected from sunlight directly.

Sunlight affects the growth of bacteria. Some types of bacteria can die from the presence of ultra violet (UV) rays contained in sunlight. The seeding process on this research was conducted on workshop/laboratory test of Environmental Health Department of Surabaya Health Polytechnic of the ministry of Health, Surabaya. The appliance is placed in a shade with a $\mathrm{pH}$ guarded at around 7.3 , while the temperature of the wastewater is maintained at the range between $31^{\circ} \mathrm{C}$. In those conditions, the growth of bacteria will be at the $\mathrm{pH}$ and optimum temperature.

Tchobanoglous in Amalia [19] stated that the Methanogen microorganisms are generally $\mathrm{pH}-$ sensitive microorganisms with a range of 6.60 to 7.60 . While the temperature that provides optimum biological reaction, rate is at the temperature of $25^{\circ} \mathrm{C}$ to $35^{\circ} \mathrm{C}$ in this study, during the average $\mathrm{pH}$ measured process is 7.3 with a temperature of $31^{\circ} \mathrm{C}$. The $\mathrm{pH}$ and temperature conditions are highly supportive or within the optimal bacterial growth range.

\subsection{Detergent content}

Detergent is an organic compound, which has two poles and is non-polar characteristic. There are three types of detergent namely anionic, cationic, and non-ionic. Anionic and permanent cationic have a negative and positive charge attached to the non-polar (hydrophobic). Anionic surfactants, often have a sodium, potassium, or ammonium group, as in sodium stearate. These are the most widely used class of surfactants due to their relatively low cost of manufacture and they are used in practically every type of detergent [20]. Anionic surfactants, in general, tend to generate more foam than other classes of surfactants. Anionic surfactants are used in greater volume than any group of surfactants due to their ease of production and low cost of manufacture [21].

Non-ionic detergents do not have a fixed ion payload, this happens because they have a weak amount of electropositive and electronegative atoms caused by the power of pulling oxygen atom electrons. Anion surfactants are one of the most important, natural and synthetic substances that demonstrate the activity of the blue methylene. The MBAS method is useful as a determination of the anion surfactant content of water and waste, but it is likely that other forms of MBAS (in addition to interactions between Blue methylene and anionic surfactants) should always be observed [22]. Surfactants (surface active agents) represent the major organic-micropollutant (OMPs) in the greywater because of the used in the generation of detergents and hygiene products, which are utilized extensively in bathing and clothes' washing [23].

In this research, the measured parameters are anionic detergents, using the methylene blue active substances (MBAS) method. Performance of bioreactors is seen with the efficiency of decreased detergent content. The efficiency of the reduction of detergent content using Biofilter reactors using coagulation, flocculation, bioball, and activated charcoal is achieved an average yield of $94.1 \%$. Sample detergent before processing $14.56 \mathrm{mg} / \mathrm{L}$ and after going through the processing process to $0.86 \mathrm{mg} / \mathrm{L}$. Reduced detergent levels in the biofilters body in the study showed a slow decline and continued to decline with the length of time taken with a 15-minute interval. The biofilter used is a hollow biofilter so that it has an optimal surface area for bacterial growth. Media that is hollow reduces the risk of deadlock [24]. At the last 15 minutes it has gained the result that a reduced level of detergent is measured at $94.1 \%$. This indicates that the body with coagulation, flocculation, and sedimentation combined with the biofilters body with bioball and activated charcoal has resulted in a significant reduction in the potential for reducing the detergent levels in the sample water [8]. Decreased levels of detergent caused by the properties of coagulant material. Several methods that have been reported to reduce surfactant and phosphate levels are biodegradation, electrocoagulation, membranes and biofilers [26]. Coagulants are needed to separate the dissolved solids or are suspended solid because naturally the deposition rate is very slow. Meanwhile, the addition of coagulants used in this research is Tawas $\left(\mathrm{Al}_{2} \mathrm{SO}_{4}\right)$ where more and more molecules of hydrate are more and more opponent ions are then tied up but generally less stable [1]. 


\subsection{Analisis of experiment results and interpretation of research results}

This research aims to design a bioreactor tool to process detergent waste to meet the specified raw. The results of the experiment were then in the analysis and interpretation according to the research results through laboratory examination. Performance of $b$

Bioreactors is seen with the efficiency of decreased detergent content. Laboratory test results on the content of detergent after processing will be compared with the quality standards established by the Governor of East Java. Laboratory results in this study showed that processing through bioreactors consisting of two calculated body effectively lowers the level of detergent. Decreased detergent levels in this research is very significant. The average level of detergent before processing is $14.56 \mathrm{mg} / \mathrm{L}$ and dropped to $0.86 \mathrm{mg} / \mathrm{L}$ after going through the processing process using a bioreactor tool designed in this study. There was a decrease of $13.7 \mathrm{mg} / \mathrm{L}$ or a reduced detergent rate of $94.1 \%$. The reduction in detergent of $94.1 \%$ was a much better result than the previous research conducted by Astrid et al [12]. The research only uses biofilters tubs using bioball and active charcoal. The reduction of detergent from the research results amounted to $31.98 \%$. Reduction efficiency of detergent content is caused by the properties of coagulant material. Coagulants are needed to separate the dissolved solids or are suspended solid because naturally the deposition rate is very slow. Coagulation method is useful for the pre-treatment process of the industrial wastewater soaps and prerequisite prior to biological treatment [27], [28]. Meanwhile, the addition of coagulants used in this research is Tawas $\left(\mathrm{Al}_{2} \mathrm{SO}_{4}\right)$ where more and more molecules of hydrate are more and more opponent ions are then tied up but generally less stable [1]. Decreased levels of detergent are also caused by filtration processes using active charcoal and bioball. According to Said and Herlambang activated charcoal increases the efficiency of removing organic substances in liquid waste [29], bioball is used as a filtration medium because it is lightweight, easily rewashed, and has the most specific surface area in comparison with other types of biofilters media. It has a size of $200-240 \mathrm{~m} 2 / \mathrm{m} 3$. In addition, bioball is chosen as a media filtration because it serves as a living place of bacteria-bacteria that are needed to maintain the quality of water. Bacterial growth on the bioball can form a biofilm layer which can affect the decrease in surfactants. In the research of Xu, Wang and Xing, the main factors that affect the foaming ability and stability of the surfactants are the interface stress and the properties of the film or the intensity of the film adsorption [30], [31]. The pollutant compounds present in the wastewater will diffuse into a layer or biofilm attached to the surface of the medium.

Bioreactors have two conditions aerobic and anaerobic. Anaerobic conditions in the bioreactor can form $\mathrm{H} 2 \mathrm{~S}$ gas, if the available oxygen is large enough, the $\mathrm{H} 2 \mathrm{~S}$ gas will be converted by bacteria into sulfate (SO4). This indicates the occurrence of the surfactant decomposition process in the sample [32]. This anaerobic-aerobic bio filters system is quite simple, easy operation, and without chemicals and without requiring a lot of energy [1], [5]. Waste water detergent is channeled into biofilter reactor, existing microorganisms will outline the organic substances in the detergent waste and will stick to the surface of Bioball. The results of the experiments in this study showed that filtration using the modification of the body with Biofilters using bioball and activated charcoal can reduce the level of detergent so as to meet the maximum required level of East Java Governor Regulation Number 72 in 2013. In the struggle of East Java number 72 in 2013 about the quality of waste water for industrial and/or other business activities stated that the quality standard of wastewater/detergent maximum limit is $3 \mathrm{mg} / \mathrm{L}$.

\section{CONCLUSION}

Reactor biofilters designed by using a control tank (coagulation, flocculation and sedimentation) and modified with a biofilters body using bioball and activated charcoal to produce a reduction of detergent effectively. Optimum condition of bacterial growth when seeding within two weeks can be achieved by controlling $\mathrm{pH}$ about 7.3 and temperature between $25^{\circ} \mathrm{C}-37^{\circ} \mathrm{C}$, and $\mathrm{pH}$ between $6.5-7.5$. Reduction of detergent content of the research using reactor biofilters very significant modification of $94.1 \%$ (from 14.56 $\mathrm{mg} / \mathrm{l}$ to $0.86 \mathrm{mg} / \mathrm{l}$ ). Effectiveness of biofilters reactor equipment in lowering the detergent content of $94.1 \%$ $(0.86 \mathrm{mg} / \mathrm{L})$ far below the standard of the governor of East Java No. 72 in 2013 of $3 \mathrm{mg} / \mathrm{L}$. Inorganic material has considerable ability in filtering material contained in detergent waste for that utilization of inorganic materials need to be community, to process household waste such as detergent. Biofilters reactors in the processing of detergent waste designed in this research proved effective and environmentally sound, so it is necessary to be sought to be socialized to the community, especially for laundry managers.

\section{REFERENCES}

[1] GO Bianchetti, CL Devlin, and KR Seddon, "Bleaching systems in domestic laundry detergents: a review," RSC Advances Journal, vol. 5, no. 80, pp. 65365-65384, 2015, doi: 10.1039/C5RA05328E.

[2] Chandra and Budiman, Introduction to Environmental Health. Jakarta: EGC Medicine, 2012 
[3] Haderia and N. U. Dewi, "Minimizing Detergent Levels with the Addition of Coagulants and Filter Media Filtration in Bathroom Waste (In Indonesia: Meminimalkan Kadar Deterjen dengan Penambahan Koagulan dan Filtrasi Media Filter pada Limbah Kamar Mandi)", Journal of Hygiene, vol. 1, no. 1, January - April 2015, ISSN: 2443-1141, 2015.

[4] Padmaningrum, T. Aminatun, and Yuliati, "Effect of Water Jasmine Biomass (Echinodorus Paleafolius) and Lotus (Nyphaea Firecrest) on Phosphate, BOD, COD, TSS, and the Degree of Acidity of Laundry Liquid Waste (In Indonesia: Pengaruh Biomassa Melati Air (Echinodorus Paleafolius) dan Teratai (Nyphaea Firecrest) terhadap Fosfat, BOD, COD, TSS, dan Tingkat Keasaman Limbah Cair Laundry)," Journal of Scientific Research, vol. 19, no. 2, pp. $65-74,2014$

[5] F. Dewi, M. Faisal, and Mariana, "Efficiency of Phosphate Absorption of Laundry Waste Using Water Spinach (Ipomoea Aquatic Forsk) and Jeringau (Acorus Calamus) (In Indonesia: Efisiensi Penyerapan Fosfat Limbah Laundry Menggunakan Bayam Air (Ipomoea Aquatic Forsk) dan Jeringau (Acorus Calamus))," Journal of Chemical Engineering, vol. 4, no. 1, pp. 7-10, 2015.

[6] Rakhmawati, A. Puspa and N. Karnaningroem, "Laundry Wastewater Treatment with Biofilter Reactors and Flocculation Coagulation" (In Indonesia: Pengolahan Air Limbah Laundry dengan Reaktor Biofilter dan Koagulasi Flokulasi)," Proceedings of the National Seminar on Technology Management XVI: E-2.1 - 2.8. Surabaya: ITS. ISBN 978-602-97491-5-1, 2012. [Online]. Available: http://mmt.its.ac.id/download/SEMNAS/SEMNAS XVI/MTL/2. Anasia Puspa Rakhmawati.pdf

[7] Switarto, Bambang and Sugito, "Application of Aerobic Biofilter to Reduce Detergent Content in Laundry Wastewater (In Indonesia: Penerapan Biofilter Aerobik untuk Mengurangi Kadar Deterjen pada Air Limbah Laundry)," Time Engineering Journal, vol. 1, no. 2, pp. 23-31, 2012.

[8] Puspitathati, Cony, "Study of Bio sand Filter Performance in Processing Laundry Waste with Phosphate Parameters," (In Indonesia: Kajian Kinerja Bio Sand Filter Dalam Pengolahan Limbah Laundry dengan Parameter Fosfat), Journal of the Department of Environmental Engineering, FTSP-ITS, 2012.

[9] Astuti S. Widya and S. M. Suriani, "Laundry Waste Treatment Using the Bio sand Filter Method to Degrade Phosphates (In Indonesia: Pengolahan Limbah Laundry Menggunakan Metode Bio sand Filter untuk Mendegradasi Fosfat)," Journal of Chemical Engineering, vol. 4, no. 2, pp. 53-58, 2015.

[10] Wibowo A. Y. and Putra A, "The Effect of Pumice Stone Particle Size on the Absorption Ability of Heavy Metal Waste' (In Indonesia: Pengaruh Ukuran Partikel Batu Apung terhadap Kemampuan Serap Limbah Logam Berat)," Journal of Physics Unand, vol. 2, no. 3, pp. 155-161, 2013.

[11] T. Suarbawa, I. Komang and A. Munawar, Anaerobic Fixed Bed Reactors to Reduce COD, Phosphate (PO4) and Detergent (LAS)" (In Indonesia: Reaktor Tempat Tidur Tetap Anaerobik untuk Mengurangi COD, Fosfat (PO4) dan Deterjen (LAS)), Environmental Engineering Scientific Journal, vol. 6, no. 2, pp. 65-72, 2015.

[12] A. R. Hapsari, H. Suryono, and P. Hermiyanti, "Comparison of the Effectiveness of Tile and Bioball Biofilter Media in Reducing Detergent Levels of Laundry Waste (In Indonesia: Perbandingan Efektivitas Media Biofilter Ubin dan Bioball dalam Menurunkan Kadar Deterjen Limbah Laundry)," E-Journal of Environmental Health Echoes, vol. 14, no. 3, pp. 162-165, 2016.

[13] P. Arroyo and M. M. Senante, "Selecting Appropriate Wastewater Treatment Technologies Using a Choosing by Advantages Approach," Science of The Total Environment, vol. 625, pp. 819 -827, 2018.

[14] Notoadmodjo. S, Health Research Methods. Jakarta: PT Asdi Mahasatya, 2012.

[15] T. K. Trinh and L. S. Kang, "Response Surface Methodological Approach to Optimize the CoagulationFlocculation Process in Drinking Water Treatment," Chemical Engineering Research and Design, vol. 89, vol. 7, pp. $1126-1135,2011$.

[16] East Java Governor Regulation Number 72, Concerning Wastewater Quality Standards for Industry and /or Other Business Activities, 2013.

[17] Borchate, S.S. Kulkarni, G.S. Kore, S.V. Kore V.S. "A review on Application of Coagulation-Flocculation and Ballast Flocculation for Water and Waste water," International Journal of Innovations in Engineering and Technology, vol. 4, no. 4, pp. 216-223, 2014.

[18] Muliartha and I. Ketut, "Technical Guidelines for Small Industry Liquid Waste Management. Jakarta: Ministry of Environment (In Indonesia: Pedoman Teknis Pengelolaan Limbah Cair Industri Kecil. Jakarta: Kementerian Lingkungan Hidup)," $2004 . \quad$ [Online]. Available: http://www.kelair.bppt.go.id/Publikasi/BukuPetnisLimbLH/01DASAR.pdf

[19] Ananda, Hartati and Salafudin, "Seeding and Acclimatization in Two Stage Anaerobic Processes using a Fixed Bed Reactor" (In Indonesia: "Pembibitan dan Aklimatisasi dalam Proses Anaerobik Dua Tahap dengan Reaktor Ranjang Tetap)," Journal of Environmental Engineering Online, vol. 6, no. 1, 2017.

[20] J. Zhang, Y. Zhang, W. li, and X. li, "Optimizing Detergent Formulation with Enzymes," Journal of Surfactants and Detergents, vol. 17, no. 6, pp. 1059-1067, 2014.

[21] K. C. Cheng, Z. S. Khoo, N. W. Lo, W. J. Tan, and N. G. Chemmangattuvalappil, "Design and performance optimisation of detergent product containing binary mixture of anionic-nonionic surfactants," Hellion, vol. 6, no. 5, CellPress, 2020. 
[22] Astuti S.W. and Sinaga M.S, "Comparison of Anionic Surfactant Determination with UV-ST Spectrophotometer Using Green and Methylene Blue Malasite Complexes (In Indonesia: Perbandingan Penentuan Surfaktan Anionik dengan Spektrofotometer UV-ST Menggunakan Kompleks Malasit Hijau dan Metilen Biru)," Journal of Environmental Chemistry, vol. 4, no. 2, pp.53-58, 2015.

[23] R.M. Mohammed, A.A.A Geethy, J. Noramira, C.M. Chan, M.K. Amir Hashim, and M. Sabariah, "Effect of detergents from laundry greywater on soil properties: a preliminary study," Applied Water Science, vol. 8, no. 16, 2018.

[24] V. Rocher AM. Laverman, J. Gasperi, and S. Azimi, "Nitrite Accumulation During Denitrification Depand on the Carbon Quality and Quantity in Wastewater Treatment with Biofilters," Environmental Science and Pollution Research, vol. 22, no. 13, pp. 10179-10188, 2015, doi: 10.1007/s11356-015-4196-1.

[25] N. Apriyani, "Decreased levels of surfactants and sulphates in laundry waste" (In Indonesia: Penurunan kadar surfaktan dan sulfat pada limbah laundry)," Media of Environmental Engineering Scientific, vol. 2, no. 1, pp. 3744, 2017.

[26] A. Aygun and T. Yilmaz, "Improvement of Coagulation-Flocculation Process for Treatment of Detergent Wastewaters Using Coagulant Aids," International Journal of Chemical and Environment Engineering, vol. 1, no. 2, pp. $97-101,2010$.

[27] Chatoui, M. Lahsaini, S. Souabi, S. Bahlaoui, and M. Jada, "A Removal of Wastewater Soaps by Coagulation Flocculation Process," Journal of Colloid Science and Biotechnology, vol. 5, no. 2, pp. 212-217, 2016.

[28] Said. N. I and Herlambang. A, "Improvement of Raw Water Quality by Submerged Biofiltration Process Using Honeycomb Tube Structure Media (In Indonesia: Peningkatan Kualitas Air Baku Dengan Proses Biofilter Tercelup Menggunakan Media Struktur Sarang Tawon),"Jurnal Air Indonesia, vol. 7, no. 1, pp. 21-31, 2014.

[29] M. S. Kamal, "A Review of Gemini Surfactants: Potential Application in Enhanced Oil Recovery," Jurnal of Surfactants and Detergents, vol. 19, no. 2, pp. 223-236, 2015.

[30] Q. Xu, L. Wang and F. Xing, "Synthesis and Properties of Dissymmetric Gemini Surfactants," Journal of Surfactants and Detergents, vol. 14, no. 1, pp. 85-90, 2011, doi:10.1007/s11743-010-1207-6.

[32] Said. N. I, "Domestic Wastewater Treatment in DKI Djakarta Overview of Problems, Strategies and Treatment Technology (In Indonesia: Pengolahan Air Limbah Domestik di DKI Jakarta Gambaran Umum Masalah, Strategi dan Teknologi Pengolahan)," Jakarta: Centre for Environmental Technology, 2008. 